\title{
PENERAPAN STRATEGI PEMBERDAYAAN MASYARAKAT MELALUI PROGRAM KETERAMPILAN PRODUKTIF DI PKBM RAWASARI
}

\author{
Puji Hadiyanti*
}

\begin{abstract}
The development of human potential through community-based educational activities aims at understanding and identifying needs and solutions that make the community itself taking into account the potential that exists in the environment. Therefore PKBM (Community Learning Center) is one of the institutions to explore and develop community-based education. The objective of this study to describe the implementation of the strategy undertaken by PKBM Rawasari in empowering the community through productive skills. The study includes the selection of the target area programs, socialization of the programs, program implementation and monitoring and evaluation of community empowerment, as well as its influence on the economic changes in the society. The method used was descriptive qualitative. The collected data were analyzed descriptively and qualitatively. The data were analyzed using percentage calculation to be interpreted and described in words. The results of the study show that the productive skills program held PKBM Rawasari is not an optimal strategy in a holistic community empowerment. However, some benefits have been felt by the program participants.
\end{abstract}

Keywords : community empowerment strategy, productive skills, community learning center

\begin{abstract}
Abstrak
Pengembangan sumber daya manusia melalui kegiatan pendidikan berbasis masyarakat untuk memahami dan mengidentifikasi kebutuhan dan cara memenuhinya dengan memperhitungkan kemampuan yang ada di lingkungan masyarakat itu sendiri. Oleh karena itu, PKBM merupakan salah satu lembaga yang berperan untuk mengkaji dan mengembangkan pendidikan berbasis masyarakat. Penelitian ini bermaksud menggambarkan strategi yang diterapkan oleh PKBM Rawasari dalam memberdayakan masyarakat melalui program keterampilan produktif. Aspek-aspek yang diteliti termasuk penentuan sasaran program, sosialisasi program, pelaksanaan, monitoring, serta evaluasi pemberdayaan masyarakat di samping pengaruhnya terhadap perubahan ekonomi masyarakat. Metode yang dipergunakan adalah kulitatif deskriptif dan data yang diperoleh dianalisis secara kuantitatif dan kualitatif dengan menggunakan persentase yang kemudian dideskripsikan secara naratif. Hasil penelitian ini menunjukkan bahwa dalam program keterampilan produktif strategi pemberdayaan masyarakat belum optimal, sungguhpun peserta program dapat merasakan manfaatnya.
\end{abstract}

Kata-kata kunci: strategi pemberdayaan masyarakat, keterampilan produktif, pusat kegiatan belajar masyarakat

\section{PENDAHULUAN}

\section{Latar Belakang}

Kegiatan membangun masyarakat terkait erat dengan memberdayakan masyarakat karena di samping memerangi kemiskinan dan kesenjangan, juga mendorong masyarakat menjadi lebih aktif dan penuh inisiatif. Pemberdayaan masyarakat sendiri merupakan upaya untuk memandirikan masyarakat, lewat perwu-

*Dosen Jurusan PLS FIP UNJ judan potensi kemampuan yang dimiliki. Pengembangan potensi manusia salah satunya dapat diwujudkan melalui kegiatan pendidikan berbasis kemasyarakatan dengan menekankan pentingnya memahami kebutuhan masyarakat dan cara pemecahan permasalahan oleh masyarakat dengan memperhatikan potensi yang ada di lingkungannya. Pendidikan yang bertumpu pada masyarakat adalah pendidikan yang diselenggarakan masyarakat, berada di tengah masyarakat, mengan- 
dalkan kekuatan masyarakat, menjawab kebutuhan masyarakat, dan pengelolaan pendidikan ada ditangan masyarakat. Pendidikan yang bertumpu pada masyarakat mengarah pada pemandirian masyarakat dalam mengelola pendidikannya. Semua badan instansi atau organisasi dapat mengambil bagian di dalam pendidikan yang bertumpu pada masyarakat, karena tujuannya adalah untuk memberdayakan masyarakat secara keseluruhan, tidak mengadakan pembedaan, serta tidak mengendalikan jalannya pendidikan, karena pendidikan ini adalah milik masyarakat. Dengan demikian, orientasinya adalah kebutuhan sekarang. Namun, tidak menutup kemungkinan untuk menyiapkan masyarakat melanjutkan pendidikan ke jenjang yang lebih tinggi. Sebagai contohnya adalah kegiatan yang diselenggarakan oleh lembaga Pusat Kegiatan Belajar Masyarakat (PKBM) yaitu Kejar Paket A, Kejar Paket B, dan Kejar Paket $C$ yang tujuannya adalah untuk menjembatani kebutuhan masyarakat yang tidak mampu mengikuti jenjang pendidikan pada jalur sekolah.

PKBM itu sendiri merupakan salah satu strategi perwujudan yang telah, sedang, dan akan terus dirintis dan diselenggarakan untuk menggali dan menumbuhkembangkan pendidikan berbasis kemasyarakatan. Hal tersebut merupakan konsep dan aspek acuan kerja pendidikan luar sekolah (PLS). Selain kegiatan kejar paket, terdapat pula program pemberdayaan dalam bentuk ketrampilan produktif yang berorientasi pada kebutuhan sekarang, diantaranya adalah kursus-kursus yang diperuntukan bagi kaum ibu, remaja putri ,dan para pemuda, seperti kursus menjahit, sablon, montir, dan memasak. Semuanya itu bertujuan untuk meningkatkan keterampilan dan produktifitas masyarakat sehingga menjadi mandiri yang pada akhirnya meningkatkan taraf hidup masyarakat.

Berdasarkan paparan di atas, maka perlu dikembangkan sebuah strategi pemberdayaan masyarakat yang nantinya akan membantu masyarakat lebih berdaya, karena selama ini belum ditemukan hasil atau perubahan nyata sebagai dampak apakah program ini cukup efektif untuk memberdayakan masyarakat. Keberhasilan program tentu tidak terlepas dari strategi yang diterapkan dalam proses pelaksanaan program, untuk mengetahui hal ini diperlukan pengkajian untuk menggambarkan proses tersebut. Dari penggambaran proses pelaksanaan program, dapat diketahui apakah program tersebut telah sesuai dengan strategi pemberdayaan masyarakat.

\section{Masalah Penelitian}

Permasalahan penelitian ini adalah (1) Apakah program-program yang ada di PKBM Rawasari wujud dari pemberdayaan; (2) Sejauhmana program-program yang ada di PKBM Rawasari dapat memberdayakan masyarakat; (3) Bagaimana program-program yang ada di PKBM Rawasari dapat terealisasi sehingga mencapai tujuan; dan (4) Upaya-upaya apa saja yang dilakukan oleh PKBM Rawasari dalam memberdayakan masyarakat.

\section{KAJIAN TEORETIS}

\section{Konsep Strategi Pemberdayaan Masyarakat}

Strategi adalah cara untuk mengerahkan tenaga, dana, daya, dan peralatan yang dimiliki guna mencapai tujuan yang ditetapkan. Arti pemberdayaan masyarakat itu sendiri adalah suatu proses yang mengembangkan dan memperkuat kemampuan masyarakat untuk terus terlibat dalam proses pembangunan yang berlangsung secara dinamis sehingga masyarakat dapat menyelesaikan masalah yang dihadapi serta dapat mengambil keputusan secara bebas (independent) dan mandiri (Sumaryo, 1991). Senada dengan itu, Margono (2000) mengemukakan pemberdayaan masyarakat adalah mengembangkan kondisi dan situasi sedemikian rupa hingga masyarakat memiliki daya dan kesempatan untuk mengembangkan kehidupannya tanpa adanya kesan bahwa perkembangan itu adalah hasil kekuatan eksternal, masyarakat harus dijadikan subjek bukan objek. Sementara menurut Moeljarto (2000), menyatakan bahwa pemberdayaan masyarakat banyak diten- tukan oleh akses dan kontrol yang dimiliki subjek pembangunan itu pada berbagai sumber daya. Sumber daya pembangunan yang utama adalah modal, terma-suk didalamnya kepintaran, ketrampilan, informasi, dan teknologi di samping dana dan tanah. Pemberdayaan masyarakat dipengaruhi oleh faktor internal dan eksternal. Hikmat (2001: 12) menjelaskan ada beberapa faktor internal yang menghambat pemberdayaan antara lain kurang bisa untuk saling mempercayai, kurang daya inovasi/ kreativitas, mudah pasrah/ menyerah/ putus asa, aspirasi dan cita-cita rendah, tidak mampu menunda menikmati hasil kerja, wawasan waktu yang sempit, familisme, sangat tergantung pada bantuan pemerintah, sangat terikat pada tempat kediamannya, dan tidak mampu/ tidak bersedia menempatkan diri sebagai orang lain.

Bagaimana memberdayakan masyarakat merupakan suatu masalah tersendiri yang berkaitan dengan hakikat dari power atau daya (mengandung pengertian 
"kemampuan", "kekuatan", ataupun "kekuasaan", serta hubungan antar individu atau lapisan sosial yang lain. Pada dasarnya, setiap individu dilahirkan dengan daya. Hanya saja kadar daya itu akan berbeda antara satu individu dengan individu yang lain. Kondisi ini dipengaruhi oleh berbagai faktor yang saling terkait (interlinking factors) seperti pengetahuan, kemampuan, status, harta, kedudukan dan jenis kelamin. Faktor-faktor yang saling terkait tersebut pada akhirnya membuat hubungan antarindividu, dengan dikotonomi subjek (penguasa) dan objek (yang dikuasai) yang meliputi kaya-miskin, laki-laki-perempuan, guru-murid, pemerintah-warganya, antaragen pembangunan dan si miskin, dan lain sebagainya. Bentuk relasi sosial yang dicirikan dengan dikotomi subjek dan objek tersebut merupakan relasi yang ingin "diperbaiki" melalui proses pemberdayaan.

Pemberdayaan merupakan proses pematahan atau breakdown dari hubungan atau relasi antara subjek dengan objek. Proses ini mementingkan adanya 'pengakuan' subjek akan "kemampuan" atau "daya" (power) yang dimiliki objek. Secara garis besar, proses ini melihat pentingnya mengalirnya daya (flow of power) dari subjek ke objek dengan memberinya kesempatan untuk meningkatkan hidupnya dengan memakai sum-ber yang ada merupakan salah satu manifestasi dari mengalirnya daya tersebut. Pada akhirnya, kemampuan individu miskin untuk dapat mewujudkan harapannya dengan diberinya "pengakuan" oleh subjek merupakan bukti bahwa individu tersebut mempunyai daya.

Dengan kata lain, mengalirnya daya ini dapat berwujud suatu upaya dari objek untuk meningkatkan hidupnya dengan memakai daya yang ada padanya serta dibantu juga dengan daya yang dimiliki subjek. Dalam pengertian yang lebih luas, mengalirnya daya ini merupakan upaya atau cita-cita untuk mengintegrasikan masyarakat miskin ke dalam aspek kehidupan yang lebih luas. Hasil akhir dari proses pemberdayaan adalah beralihnya fungsi individu yang semula objek menjadi subjek (yang baru), sehingga relasi sosial yang ada nantinya hanya dicirikan dengan relasi antar subjek dengan subjek yang lain. Dengan kata lain, proses pemberdayaan mengubah pola relasi lama subjek-objek menjadi subjek-subjek.

Hal ini merupakan prasyarat krusial dalam mewujudkan makna pemberdayaan masyarakat secara utuh. Hubungan yang timpang atau yang menghalalkan bentuk hubungan yang subordinat atau asimetris cenderung mengabadikan penindasan dan kemiskinan. Peralihan fungsi objek menjadi subjek baru merupakan tantangan dalam segala macam implementasi kebijakan. Masih banyak ditemukan kebijakan dengan dalih pemberdayaan dan membantu yang miskin, tetapi masih menempatkan objek pada posisinya semula. Artinya, masyarakat miskin tetap sebagai pihak yang "dikontrol dan dikuasai" oleh subjek.

Seringkali, mengalirnya daya untuk mengalihfungsikan individu miskin yang semula objek menjadi subjek ini tidak dapat terwujud dengan baik. Kondisi tersebut dapat memunculkan countervailing power dari objek yang dipakai untuk "menantang" konfigurasi daya (power) yang sudah mapan. Objek bisanya akan dibantu oleh pihak luar yang berkepentingan sama, misalnya LSM. Proses tersebut juga berkaitan dengan penciptaan aset, yaitu menciptakan suatu dasar ekonomi minimum untuk kelompok yang selama ini tersingkir. Asumsinya, dengan peningkatan taraf hidup melalui penciptaan aset tersebut, lapisan miskin akan memiliki means to intervene yang lebih kuat di dalam proses pembangunan.

Sayogyo (1999: 6) mengemukakan bahwa untuk merangsang lahirnya gerakan masyarakat yang bermula pada komunitas lokal, ada sejumlah syarat yang terlebih dahulu harus dipenuhi. Tiga syarat terpenting adalah.

1. Restrukturisasi kelembagaan komunitas. Tatanan dasar yang mengatur kehidupan komunitas perlu direorientasi (UU politik dan pemerintahan), dari yang pola feodalistik dan kolonial (pemerintahan yang kuat dan paternalistik) ke pola pemerintahan yang lebih profesional dan masyarakat yang dinamis. Tatanan baru perlu menjamin kebebasan masyarakat berekspresi dan mengembangkan inisiatif lokal untuk memenuhi kebutuhan-kebutuhan asasinya. Masyarakat harus menjadi subjek dan penentu utama dari segala kegiatan pembangunan dalam arti yang sesungguhnya.

2. Meninjau kembali segala kebijakan yang memperlemah kebudayaan masyarakat dan menggantinya dengan kebijakan yang lebih memihak pada upaya peningkatan keberdayaan masyarakat desa untuk memperbaiki nasib sendiri.

3. Pada arah program, pendekatan top-down harus segera diganti pendekatan bottom up, yang tercermin dari mekanisme pengambilan keputusan dan penyelenggaranaan program. Istilah program pengembangan masyarakat seharusnya tidak lagi berkonotasi program masuk desa, melainkan program dari desa. Artinya, dalam segala kegiatan pembangunan desa masyarakat desa itulah yang menjadi subjek dan pelaku utama. Mulai dari penjajakan masalah dan kebutuhan, perencanaan, pelaksanaan, pegawasan, dan evaluasi sampai pemanfaatan hasil-hasilnya. Dalam keadaan demikian, masyarakat akan menerima kegagalan maupun 
keberhasilan program secara bertanggung jawab.

Dengan demikian dapat, dikatakan bahwa strategi pemberdayaan masyarakat adalah cara untuk mengaktualisasikan potensi yang sudah dimiliki oleh masyarakat, sehingga pendekatan pemberdayaan masyarakat adalah penekanan pentingnya masyarakat lokal yang mandiri sebagai suatu sistem yang mengorganisir diri sendiri. Pendekatan pemberdayaan yang demikian, tentunya diharapkan memberikan peranan kepada individu bukan sebagai objek tetapi sebagai pelaku (aktor) yang menentukan hidup individu dengan mengupayakan berbagai potensi yang dimilikinya.

Proses pemberdayaan masyarakat bertitik tolak untuk memandirikan masyarakat agar dapat meningkatkan taraf hidupnya sendiri dengan menggunakan dan mengakses sumber daya setempat sebaik mungkin. Sasaran utama pemberdayaan masyarakat adalah masyarakat miskin. Dalam prosesnya perlu diperhatikan bahwa perempuan akan terlibat secara aktif. Proses pemberdayaan masyarakat didampingi oleh suatu tim fasilitator yang bersifat multidisiplin. Tim pemberdayaan masyarakat sebaiknya terdiri dari laki-laki dan perempuan. Peran utama tim pemberdayaan masyarakat adalah mendampingi masyarakat dalam melaksanakan proses pemberdayaan. Peran tim pemberdayaan masyarakat pada awal proses sangat aktif tetapi akan berkurang selama proses berjalan sampai masyarakat sudah mampu melanjutkan kegiatannya secara mandiri. Pemberdayaan masyarakat dilaksanakan melalui beberapa tahapan seperti.

Tahap 1. Seleksi lokasi

Seleksi wilayah dilakukan sesuai dengan kriteria yang disepakati oleh lembaga, pihak-pihak terkait dan masyarakat. Penetapan kriteria ini penting agar tujuan lembaga dalam pemberdayaan masyarakat akan tercapai serta pemilihan lokasi dilakukan sebaik mungkin. Tahap 2. Sosialisasi pemberdayaan masyarakat

Sosialisasi pemberdayaan masyarakat adalah suatu kegiatan yang sangat penting untuk menciptakan komunikasi serta dialog dengan masyarakat. Sosialisasi pemberdayaan masyarakat membantu untuk meningkatkan pengertian pada masyarakat dan pihak terkait tentang program. Proses sosialisasi sangat menentukan ketertarikan masyarakat untuk berperan dan terlibat di dalam program.

Tahap 3. Proses pemberdayaan masyarakat

Proses pemberdayaan masyarakat terdiri dari.

(a) Kajian keadaan pedesaan partisipatif,

(b) Pengembangan kelompok,

(c) Penyusunan rencana dan pelaksanaan kegiatan,

(d) Monitoring dan evaluasi partisipatif

Maksud pemberdayaan masyarakat adalah me- ningkatkan kemampuan dan kemandirian masyarakat dalam meningkatkan taraf hidupnya (tujuan umum). Dalam proses tersebut masyarakat bersama-sama.

(a) Mengidentifikasi dan mengkaji permasalahan, potensinya serta peluang,

(b) Menyusun rencana kegiatan kelompok berdasarkan hasil kajian,

(c) Menerapkan rencana kegiatan kelompok,

(d) Memantau proses dan hasil kegiatannya secara terus menerus (monitoring dan evaluasi partisipatif (M\&EP).

Dalam semua kegiatan, sering dimanfaatkan teknik dan alat visualisasi yang mendukung diskusi antara masyarakat dan memudahkan proses pemberdayaan. Diharapkan bahwa melalui teknik-teknik tersebut, proses kajian, penyusunan rencana kegiatan, penerapan, monitoring, dan evaluasi dilakukan secara sistematis. Teknik-teknik kajian sering disebut "Participatory Rural Appraisal" atau "PRA". Monitoring dan evaluasi merupakan suatu tahap yang sangat penting dan bermaksud untuk memperbaiki proses secara terus menerus agar tujuan dapat tercapai. Aspek-aspek yang dimonitor dan dievaluasi meliputi proses, pencapaian, dan dampak proses pemberdayaan.

Tahap 4. Pemandirian masyarakat

Proses pemberdayaan masyarakat merupakan suatu proses pembelajaran terus menerus bagi masyarakat dengan tujuan kemandirian masyarakat dalam upaya-upaya peningkatan taraf hidupnya. Artinya, bahwa peran tim pemberdayaan masyarakat akan pelan-pelan dikurangi dan akhirnya akan berhenti. Peran tim pemberdayaan kelompok sebagai fasilitator akan dipenuhi oleh pengurus kelompok atau pihak lain yang dianggap mampu oleh masyarakat. Waktu yang diperlukan untuk pelaksanaan pemberdayaan masyarakat tidak tentu. Pemberdayaan masyarakat adalah suatu proses yang akan berjalan terus menerus. Seringkali kegiatan memerlukan waktu dan tidak dapat dilakukan secara terburu-buru.

\section{Konsep PKBM}

Pengertian PKBM (Pusat Kegiatan Belajar Masyarakat) adalah wadah dari berbagai kegiatan pembelajaran masyarakat yang diharapkan pada pemberdayaan potensi untuk menggerakkan pembangunan di bidang sosial, ekonomi dan budaya. PKBM merupakan tempat belajar yang dibentuk dari, oleh, dan untuk masyarakat dalam rangka usaha meningkatkan pengetahuan, keterampilan, sikap, hobi, dan bakat warga masyarakat yang bertitik tolak dari kebermaknaan dan kebermanfaatan potensi sumber daya manusia dan sumber daya alam yang ada di lingkungan (Sihombing, 2000). 
Pelembagaan PKBM dilaksanakan dengan memanfaatkan gedung-gedung SD, Balai Desa, Puskesmas yang oleh karena berbagai hal tidak dimanfaatkan lagi, seperti adanya gedung-gedung baru, sekolah swasta, dan gedung milik pribadi yang dengan rela diberikan untuk digunakan menjadi PKBM. Pembentukan PKBM dilakukan dengan memperhatikan sumber-sumber potensi yang terdapat pada daerah yang bersangkutan, terutama jumlah kelompok sasaran dan jenis usaha atau keterampilan yang secara ekonomi, sosial, dan budaya dapat dikembangkan untuk meningkatkan kesejahteraan warga belajar khususnya dan warga masyarakat sekitarnya.

Program yang digulirkan tidak terbatas pada program dari instansi pendidikan luar sekolah, tetapi juga program dari instansi lain, yang oleh masyarakat dirasakan manfaatnya, seperti perkebunan, perindustrian, pertanian, perdagangan, kesehatan, keluarga berencana, olahraga, dan lain sebagainya. Seluruh program belajar yang ada di PKBM selalu terkait dengan mata pencaharian. Hal ini seperti yang tertuang dalam visi dan misi PKBM yaitu mewujudkan PKBM sebagai tempat belajar utama dan pertama bagi masyarakat untuk mencerdaskan kehidupannya melalui jalur pendidikan luar sekolah, sedangkan misinya adalah memberikan pelayanan pendidikan, mendidik warga masyarakat untuk memenuhi segala jenis pendidikannya melalui pendidikan luar sekolah.

Adapun ciri-ciri PKBM ialah inisiatif pembentuk dari masyarakat, pengelolaan penyelenggaraan program dilakukan oleh masyarakat, perencanaan, dan penetapan program bertitik tolak dari pengalaman-pengalaman dari masyarakat yang ada, penyelenggaraan program diutamakan mendayagunakan potensi dan sumber daya masyarakat, pembiayaan diusahakan dari sumber yang ada di masyarakat, tempat strategis dan sesuai kesepakatan masyarakat, melibatkan pemerintah dan lembaga swadaya masyarakat sebagai mitra kerja dalam penyelenggaraan program kegiatannya dan memberikan layanan pendidikan baik individu maupun kelompok.

PKBM memiliki fungsi utama dan pendukung. Fungsi utama PKBM adalah sebagai wadah berbagai kegiatan belajar masyarakat untuk meningkatkan pengetahuan, keterampilan, dan sikap yang diperlukan untuk mengembangkan diri dan masyarakat. Fungsi pendukung dari PKBM adalah sebagi pusat informasi bagi masyarakat sekitar dan pemerintah, pusat jaringan informasi dan kerja sama bagi lembaga di luar masyarakat, sebagai tempat koordinasi, konsultasi, komunikasi, dan sebagai tempat kegiatan penyebarluasan program dan teknologi tepat guna.

\section{Konsep Pelaksanaan Program Keterampilan Produktif di PKBM}

Program keterampilan produktif merupakan salah satu kegiatan pemberdayaan masyarakat yang bertumpu pada pendidikan berbasis masyarakat, dalam melaksanakan kegiatan pendidikan yang berbasis masyarakat terdapat empat hal unsur yaitu.

1. Mementingkan warga belajar. Di sini ada beberapa penekanan seperti pentingnya mendengar suara warga belajar, gunakan apa yang dikatakan warga belajar sebagai dasar untuk mengembangkan program belajar, dan percayalah setiap orang punya kemampuan belajar karena setiap warga belajar memiliki kekuatan, keterampilan, pengetahuan, dan pengalaman.

2. Kesetaraan di antara warga belajar dan pembina program mendorong warga belajar agar ikut aktif terlibat dalam kegiatan belajar dan kegiatan kemasyarakat. Perhatikan kebutuhan belajar masyarakat, karena masyarakat sebenarnya tahu apa yang dibutuhkan.

3. Program dimulai dari perspektif yang kritis, menggunakan pendekatan kritis yang menekankan pentingnya perbaikan kemampuan dasar masyarakat, meningkatkan kemampuan yang sudah ada dan partisipasi dalam setiap kegiatan.

4. Pembangunan masyarakat, menekankan bahwa program belajar harus berlokasi di masyarakat, menjawab kebutuhan belajar masyarakat, menciptakan rasa memiliki, dirancang, diputuskan dan diatur oleh masyarakat, sehingga masyarakat merupakan bagian dari yang lebih besar.

Unsur-unsur tersebut akan dapat dicapai dengan menempuh hal-hal berikut.

1. Kegiatan belajar dilakukan dalam kelompok kecil atas dasar kesamaan minat.

2. Tutor atau narasumber secara berangsur-angsur harus dapat menyerahkan tanggung jawab kegiatan belajar kepada peserta.

3. Sedapat mungkin kepemimpinan diserahkan kepada peserta/ warga belajar.

4. Pendamping berperan sebagai fasilitator.

5. Semua keputusan harus dibuat secara mufakat di antara peserta/ warga belajar.

6. Kegiatan belajar senantiasa berdasarkan pengalaman-pengalaman dan masalah-masalah yang dihadapi oleh peserta.

7. Metode dan teknik yang digunakan sesuai dengan kondisi warga belajar .

8. Bahan belajar diarahkan pada kebutuhan/kenyataan hidup sehari-hari peserta.

Schwartz (dalam Suharto, 2006) menge- 
mukakan lima tugas yang dapat dilaksanakan oleh penyelenggara program pemberdayaan masyarakat, yaitu.

1. Mencari persamaan mendasar antara persepsi masyarakat mengenai kebutuhan diri sendiri dan aspek-aspek tuntutan sosial yang dihadapi.

2. Mendeteksi dan menghadapi kesulitan-kesulitan yang menghambat banyak orang dan membuat frustasi usaha-usaha orang untuk mengidentifikasi kepentingan masyarakat dan kepentingan orangorang yang berpengaruh terhadap masyarakat.

3. Memberikan kontribusi data mengenai ide-ide, fakta, nilai, konsep yang tidak dimiliki masyarakat, tetapi bermanfaat bagi masyarakat dalam menghadapi realitas sosial dan masalah yang dihadapinya.
4. Membagi visi kepada masyarakat, harapan dan aspirasi penyelenggara merupakan investasi bagi interaksi orang dan masyarakat dan bagi kesejahteraan individu dan sosial.

5. Mendefinisikan syarat-syarat dan batasan-batasan situasi dengan sistem relasi antara pihak penyelenggara program dan masyarakat sasaran program yang dibentuk. Aturan-aturan tersebut membentuk konteks bagi 'kontrak kerja' yang mengikat masyarakat dan lembaga. Batasan-batasan tersebut juga mampu menciptakan kondisi yang dapat membuat masyarakat dan pihak penyelenggara program pemberdayaan masyarakat menjalankan fungsinya masing-masing.

\section{METODOLOGI PENELITIAN}

Pendekatan metode yang digunakan adalah deskriptif kualitatif. Hal ini berkaitan erat dengan sifat unik dari realitas sosial yang menyangkut pola pikir, cara pandang, sikap, dan perilaku manusia, terlebih objek penelitian ini adalah lembaga (PKBM) dalam menerapkan strategi pemberdayaan terhadap warga belajar. Sumber data dalam penelitian ini adalah peserta program keterampilan produktif berjumlah 40 orang dan pengelola PKBM berjumlah empat orang, sedangkan instansi terkait dan tokoh masyarakat dalam penelitian ini sebagai informan berjumlah tiga orang. Penelitian ini bertempat di PKBM Rawasari Kecamatan Cempaka Putih Jakarta Pusat pada bulan Agustus - September 2007.

\section{HASIL PENELITIAN}

Deskripsi Hasil penelitian berdasarkan strategi pemberdayaan yang dilakukan oleh PKBM Rawasari.

\section{Seleksi Wilayah Sasaran Program}

Seleksi wilayah dilakukan sesuai dengan kriteria yang disepati oleh lembaga, pihak-pihak terkait dan masyarakat. Penetapan kriteria ini penting agar tujuan lembaga dalam pemberdayaan masyarakat akan tercapai serta pemilihan lokasi dilakukan sebaik mungkin. Dalam melakukan seleksi wilayah sasaran program, penyelenggara melakukan identifikasi wilayah sasaran program. Aspek-aspeknya meliputi.

1. Adanya masyarakat yang hidup dalam kondisi kekurangan (marginal)

Peruntukan program-program pemberdayaan masyarakat perlu satu analisa yang mendalam dalam arti prioritas pendistribusiannya harus diperhatikan. Masyarakat marginal atau masyarakat yang hidup dalam kondisi kekurangan dapat memiliki akses untuk menerima program-program pemberdayaan yang dimaksud. Hasil dari penelitian menunjukkan bahwa para warga belajar yang mengikuti kegiatan di PKBM sebanyak 29 peserta atau $72,5 \%$ merupakan ibu rumah tangga yang dalam segi ekonomi telah mapan.
Hal ini dapat dilihat dari hasil wawancara yang menyatakan bahwa para suami peserta program kebanyakan adalah pegawai negeri sipil dari Pemda serta pegawai swasta. Fakta ini mengindikasikan tidak selayaknya program-program pemberdayaan diberikan terhadap masyarakat yang kurang membutuhkan. Artinya program-program yang ada lebih tepat sasaran terhadap golongan masyarakat tertentu yang jelas-jelas berada dalam kondisi kekurangan.

2. Dukungan dari aparat terkait dan tokoh masyarakat setempat

Dukungan dari aparat terkait seperti kelurahan dan kecamatan (pemerintah) merupakan hal yang sangat penting bagi penentuan lokasi program pemberdayaan, dari total 40 responden, 36 responden atau $90 \%$ menyatakan mendapat dukungan dari aparat pemerintahan. Sementara itu, responden yang menyatakan tidak mendapatkan dukungan dari aparat pemerintahan sebanyak 4 responden atau $10 \%$. Dapat disimpulkan bahwa pentingnya dukungan ini merupakan wujud kondisi yang dinamis, walau pemerintah hanya sebagai pengawas atau pemantau bagi keberlangsungan program-program pemberdayaan yang ada di 
masyarakat.

\section{Daerah aman/ tidak rawan konflik}

Penentuan wilayah program-program pemberdayaan mensyaratkan daerah yang aman atau tidak rawan konflik. Hal ini tercermin dari 35 responden atau $87,5 \%$ yang menyatakan wilayahnya aman atau tidak rawan konflik. Sementara responden yang lain tidak sependapat yang berarti wilayahnya tidak aman atau rawan dari konflik berjumlah 5 responden atau 12,3\%. Dapat diindikasikan keamanan merupakan aspek paling penting bagi keberlangsungan pelaksanaan programprogram pemberdayaan di masyarakat.

\section{Tidak ada kegiatan pemberdayan lain}

Aspek lain dalam penyeleksian wilayah pemberdayaan adalah tidak adanya program pemberdayaan lain. Penegasan frekuensi responden terhadap kenyataan tidak adanya program pemberdayaan lain sebanyak 30 responden atau $75 \%$. Sementara penegasan responden dengan kenyataan adanya program pemberdayaan lain sebanyak 10 responden atau $25 \%$. Dapat diindikasikan tidak adanya program pember-dayaan lain berarti minimnya program yang ada. Sehingga dengan adanya program tersebut masyarakat lebih merasakan manfaatnya dari berbagai segi aspek penentuan kelancaran program. Asumsi adanya program lain menjadikan tidak terkontrolnya kemajuan terhadap program-program pemberdayaan yang berlangsung dan keberminatan terhadap program pemberdayaan cenderung kurang.

\section{Sosialisasi Program Pemberdayaan Masyarakat}

Sosialisasi pemberdayaan masyarakat adalah suatu kegiatan yang sangat penting untuk menciptakan komunikasi serta dialog dengan masyarakat. Sosialisasi pemberdayaan pada masyarakat membantu untuk meningkatkan pengertian pada masyarakat dan pihak terkait tentang program. Proses sosialisasi sangat menentukan ketertarikan masyarakat untuk berperan dan terlibat di dalam program-program pemberdayaan masyarakat. Adapun mekanisme proses kegiatan sosialisasi yang dilakukan antara lain.

1. Pertemuan formal dengan tokoh masyarakat dan aparat pemerintahan.

2. Kesepakatan terhadap wilayah sasaran program.

3. Pertemuan formal dengan masyarakat.

4. Pendekatan formal penyelenggara program melalui kegiatan seperti kunjungan ke rumah dan diskusi kelompok.

5. Peran atau partisipasi masyarakat dalam proses sosialisasi.

Dari hasil penelitian, dapat dijelaskan bahwa 12 responden atau $30 \%$ menyatakan pertemuan formal dengan tokoh masyarakat dan aparat pemerintahan telah dilakukan, sedangkan sisanya 28 responden atau $70 \%$ menyatakan pertemuan formal antara tokoh masyarakat dan aparat tidak dilakukan. Dari hasil tersebut dapat dikatakan bahwa dalam tahap sosialisasi pihak pengelola kurang memberikan kesempatan kepada masyarakat untuk memperoleh berbagai informasi tentang program pemberdayaan itu sendiri, padahal dalam pertemuan formal ini masyarakat diberi kesempatan untuk menemukan sendiri permasalahan dan prioritas kebutuhan melalui proses musyawarah atau kesepakatan yang menjadi pilihannya. Selain itu, dalam pertemuan tersebut dapat digali juga informasi-informasi yang ada di masyarakat

Peran atau partisipasi masyarakat dalam proses sosialisasi terepresentasi oleh mayoritas responden dengan perolehan 33 responden atau 82,5\%. Hal ini menunjukkan peran atau partisipasi masyarakat sangat antusias untuk terselenggaranya program-program pemberdayaan, karena dengan adanya dukungan dari masyarakat sangat memungkinkan terus bergulirnya program-program pemberdayaan. Terlebih lagi jika adanya pendekatan informal penyelenggara program melalui kegiatan seperti kunjungan ke rumah dan diskusi kelompok, akan sangat memperlancar bergulirnya program di masyarakat. Namun hal tersebut belum dilakukan oleh pihak penyelenggara. Berdasarkan hasil wawancara dengan pihak penyelenggara, dikatakan bahwa proses sosialisasi dilakukan dengan mencari informasi dari ibu-ibu PKK saja sehingga masyarakat tertentu saja yang mendapatkan informasi adanya program-program pemberdayaan.

Selain melakukan mekanisme proses sosialisasi yang dipaparkan di atas, aspek-aspek yang penting dalam melakukan proses sosialisasi antara lain.

1. Mengenal penyelenggara program pemberdayaan. Di PKBM Rawasasari. Berdasarkan hasil penelitian, diketahui bahwa hampir sebagian responden tidak mengenal penyelenggara program. Hal ini dapat dilihat dari 40 responden hanya 13 responden atau $32,5 \%$ yang mengenal penyelenggara program, sementara sebanyak 27 responden atau $67,5 \%$ tidak mengenal penyelenggara program. Sangat dominannya responden yang tidak mengenal pihak penyelenggara program menunjukkan sosialisasi yang kurang dari pihak penyelenggara dan belum terbentuknya hubungan yang harmonis antara pihak penyelenggara program dengan warga belajar.

2. Penyelenggara program senantiasa bergaul dengan masyarakat. Berdasarkan hasil penelitian yang telah dilakukan, ternyata mayoritas responden yaitu 39 responden atau 97,5\% menjawab tidak. Hal ini semakin menunjukkan pergaulan yang kurang dari 
pihak penyelenggara dengan masyarakat sasaran program.

Pelaksanaan Program Pemberdayaan Masyarakat

PKBM adalah lembaga yang berorientasi pada pendidikan masyarakat dalam arti sebagai wadah berbagai kegiatan belajar masyarakat untuk meningkatkan pengetahuan, keterampilan, dan sikap yang diperlukan untuk mengembangkan diri dan masyarakat. Sasaran dari peserta program di PKBM adalah masyarakat umum yang membutuhkan layanan pendidikan yang tersedia di PKBM dan yang tidak dapat bersekolah di sekolah formal. Oleh karena itu, dalam proses kegiatannya sangat berbeda dengan pendidikan formal yaitu kegiatan yang pelaksanaannya berbasis pemberdayaan masyarakat. Berdasarkan hal tersebut, berikut hasil penelitian dari beberapa aspek yang digunakan dalam pelaksanaan program-program di PKBM.

1. Penyelenggara program menjelaskan tujuan dasar program

Berdasarkan hasil penelitian yang telah dilakukan, mayoritas responden yaitu 35 responden atau $87,5 \%$ menyatakan penyelenggara program menjelaskan tujuan dasar program, sementara hanya 5 responden atau $12,5 \%$ yang menyatakan tidak. Dengan kondisi tersebut, mengindikasikan kelancaran dari program yang digulirkan karena dengan adanya penjelasan dari pihak penyelenggara program masyarakat sasaran mengetahui manfaat dari program-program tersebut. Dari hasil wawancara, juga diungkapkan bahwa para peserta program pemberdayaan akan senantiasa mengikuti program-program yang ada di PKBM.

2. Kesesuaian program dengan kebutuhan masyarakat

Walaupun dalam proses sosialisasi pihak penyelenggara program dikatakan kurang maksimal, namun ternyata mayoritas responden yaitu 33 responden atau $82,5 \%$ menyatakan bahwa program-program yang digulirkan telah sesuai dengan kebutuhan, sedangkan responden yang menyatakan ketidaksesuaian program dengan kebutuhan dirinya hanya 7 responden atau $17,5 \%$. Hal ini dapat disimpulkan bahwa berjalan maksimal atau tidaknya proses sosialisasi yang dilakukan, masyarakat telah dapat menilai seperti apakah program yang sesuai dengan kebutuhan dirinya.

\section{Adanya pembentukan kelompok}

Kelancaran suatu program pemberdayaan yang ada di masyarakat sasaran sangat ditentukan oleh ada tidaknya kelompok dalam kegiatan tersebut, karena keberadaan suatu kelompok membuat ikatan-ikatan, baik secara emosional maupun secara fisik. Di samping itu juga, dengan dibentuknya kelompok-kelompok dalam peserta program pemberdayaan akan sangat mampu meningkatkan efektifitas pelaksanaan koordinasi dan sinkronisasi hal-hal yang penting terkait dengan pelaksanaan program pemberdayaan.

Dengan adanya kelompok, juga memungkinkan anggota kelompok bekerja sama dengan anggota yang lain baik formal maupun informal untuk berbagi pengetahuan dan pengalaman guna mencapai tujuan bersama. Pembentukan kelompok juga diperlukan dalam rangka meningkatkan kemandirian. Dari hasil penelitian, hal ini telah dilakukan dan terbukti dari 30 responden atau $75 \%$ yang menyatakan adanya pembentukan kelompok, sementara 10 responden atau $25 \%$ yang menyatakan tidak dibentuk kelompok.

4. Waktu kegiatan disesuaikan dengan peserta Program Pemberdayaan

Dari hasil penelitian yang dilakukan, ditemukan 30 responden atau $75 \%$ menyatakan ada kesepakatan waktu pelaksanaan program pemberdayaan antara pihak penyelenggara dengan peserta program pemberdayaan, sedangkan responden yang menyatakan tidak adanya kesepakatan waktu pelaksanaan program pemberdayaan antara penyelenggara dengan peserta berjumlah 10 responden atau 25\%. Dapat disimpulkan bahwa adanya keterlibatan yang aktif dari peserta program pemberdayaan masyarakat. Hal ini juga mengindikasikan adanya proses pembelajaran kepada masyarakat agar dapat menemukan cara-cara pemecahan permasalahan dan kebutuhan dari diri sendiri, sehingga kemungkinan terhentinya program pember-dayaan yang ada sangat kecil.

\section{Monitoring dan Evaluasi Penyelenggaraan} Program Pemberdayaan Masyarakat

Indikator keberhasilan suatu program pemberdayaan adalah meningkatnya kualitas hidup dari peserta program pemberdayaan. Untuk mengetahui tingkat keberhasilan suatu program pemberdayaan maka perlu adanya evaluasi yang dilakukan oleh penyelenggara program pemberdayaan. Kegiatan evaluasi adalah kegiatan yang sangat penting dalam pelaksanaan program pemberdayaan masyarakat. Dengan adanya evaluasi, maka akan diketahui sejauhmana efektifitas dan efisiensi program pemberdayaan masyarakat dilakukan. Secara umum, dikenal dua tipe evaluasi yaitu on going evaluation atau evaluasi terus menerus dan ex-post evaluation atau evaluasi akhir. Evaluasi berusaha mengidentifikasi mengenai apa yang sebenarnya terjadi pada pelaksanaan atau penerapan program. Evaluasi bertujuan untuk.

1. Mengidentifikasi tingkat pencapaian tujuan,

2. Mengukur dampak langsung yang terjadi pada kelompok sasaran,

3. Mengetahui dan menganalisis konsekuensi-konse- 
kuensi lain yang mungkin terjadi di luar rencana.

Aspek-aspek yang dimonitor dan di evaluasi meliputi proses, pencapaian, dan dampak proses pemberdayaan. Dari hasil penelitian, menunjukan pihak penyelenggara pemberdayaan masyarakat senantiasa melakukan monitoring dan evaluasi. Hal ini dinyatakan oleh mayoritas responden yaitu sebesar 37 responden atau $92,5 \%$. Sementara yang menyatakan tidak hanya 3 responden atau $7,5 \%$, hanya saja evaluasi yang dilakukan berdasarkan hasil wawancara dan pengamatan adalah evaluasi terhadap hasil pembelajaran yakni dalam bentuk penilaian hasil kegiatan yang dilakukan oleh peserta program pemberdayaan seperti untuk kursus menjahit yang dinilai adalah apakah peserta telah mampu menghasilkan suatu produk, demikian pula halnya dengan kursus memasak dan kursus hantaran. Evaluasi dilakukan hanya sebatas pada hasil kegiatan yang kemudian apabila peserta program pemberdayaan yang memiliki hasil penilaian terbaik dapat mengikuti lomba-lomba yang diadakan oleh instansi terkait seperti lomba antar PKBM yang selalu diadakan setiap bulan Juni dan September. Padahal, kegiatan evaluasi harus meliputi seluruh proses tahapan dalam penyelenggaraan kegiatan pemberdayaan masyarakat serta dampak atau pengaruh dari pelaksanaan program pemberdayaan.

Bicara tentang pengaruh dari adanya program pemberdayaan di masyarakat, ternyata dari total 40 responden yaitu sebesar 22 responden atau 55\% menyatakan adanya pengaruh yang diperoleh setelah mengikuti program pemberdayaan masyarakat di PKBM. Pengaruh yang dimaksud adalah masyarakat memperoleh keterampilan yang dapat digunakan untuk menambah penghasilan keluarga, seperti kursus hantaran yaitu keterampilan menghias barang bawaan untuk mempelai, dari hasil wawancara dapat disimpulkan bahwa peserta program pemberdayaan sangat merasakan sekali manfaat yang diperolehnya karena jenis keterampilan tersebut tidak banyak memerlukan dana yang besar, hanya membutuhkan kreatifitas dan kemauan yang besar dari peserta program pember- dayaan di samping tentunya penyaluran dari pihak penyelenggara program pemberdayaan kepada pengguna jasa.

Adanya penyaluran dari penyelenggara program kepada pihak pengguna jasa dinyatakan oleh 14 responden atau $35 \%$. Sementara yang menyatakan tidak adanya penyaluran dari pihak penyelenggara program pemberdayaan kepada pengguna jasa sebesar 26 responden atau $65 \%$. Dari hasil penelitian tersebut, dapat dikatakan bahwa dalam melakukan program pemberdayaan pihak penyelenggara belum sepenuhnya melaksanakan pemberdayaan secara holistik yang memadukan antara kegiatan-kegiatan dengan kebijakan sosial secara terintegrasi, sehingga pemberdayaan masyarakat yang demikian bukan saja kurang efektif, melainkan tidak berkelanjutan. Diibaratkan dengan analogi "ikan dan pancing”, maka meskipun kelompok sasaran (target grup) diberi ikan dan pancing sekaligus tidak akan berdaya jika seandainya kolam dan sungai yang ada disekitar telah dikuasai oleh kelompok lain. Jika demikian, tujuan program pemberdayaan masyarakat yaitu kemandirian peserta program pemberdayaan belum sepenuhnya terwujud.

\section{Pengaruh Pelaksanaan Program terhadap Perubahan Ekonomi Masyarakat}

Dilihat dari kondisi ekonomi masyarakat terutama peserta program pemberdayaan di PKBM Rawasari secara umum, tampaknya tidak ada perubahan secara signifikan terhadap peningkatan kondisi ekonomi. Walaupun pada tujuan dasar program keterampilan produktif lebih mengarah pada peningkatan ekonomi keluarga. Berdasarkan hasil penelitian, yang dilakukan dari 40 responden hanya sekitar $20 \%$ yang menyatakan ada perubahan pada kondisi ekonomi keluarga. Tidak adanya penyaluran kepada pengguna jasa menurut masyarakat disinyalir merupakan salah satu penyebabnya. Padahal menumbuhkembangkan kemitraan atau kerjasama antara PKBM dengan dunia usaha merupakan salah satu implementasi dari visi dan misi PKBM.

\section{KESIMPULAN}

Kesimpulan yang dapat diperoleh dari hasil penelitian ini adalah bahwa dalam melaksanakan program pemberdayaan pihak penyelenggara dalam hal ini PKBM Rawasari belum sepenuhnya melakukan pemberdayaan secara holistik, walaupun kebermanfaatan dari program pemberdayaan yang ada sangat dirasakan oleh peserta program pemberdayaan. Namun, dalam strategi yang dilaksanakan belum sepe- nuhnya mengacu pada konsep-konsep pemberdayaan. Seperti dalam tahap sosialisasi yang dianggap kurang maksimal sehingga program pemberdayaan yang ada kurang mengena pada sasaran yang lebih membutuhkan. Imbas dari kurangnya sosialisasi kepada masyarakat, maka hubungan antara pihak penyelenggara dengan peserta program pemberdayaanpun kurang harmonis. Begitu pula halnya dengan proses penentuan 
program pemberdayaan yang kurang melibatkan masyarakat, sehingga program-program yang ada hanya dibatasi oleh adanya ketersediaan dana yang ada. Di samping juga tidak adanya penyaluran dari pihak penyelenggara program kepada pengguna jasa, beberapa rekomendasi yang dapat disampaikan kepada para pengambil kebijakan terhadap permasalahan yang ada dilapangan dan untuk mengoptimalkan program pemberdayaan masyarakat adalah sebagai berikut (1) dalam melaksanakan program pemberdayaan masyarakat, sebaiknya peserta program merupakan masyarakat yang memang benar-benar membutuhkan, masyarakat dilibatkan dalam proses perumusan program, karena program yang didasari atas kebutuhan masyarakat akan lebih mempengaruhi masyarakat untuk bertanggung jawab terhadap program dan keberhasilannya; (2) hendaknya dilakukan proses sosialisasi secara pasif sebelum pelaksanaan program pemberdayaan; (3) pendampingan kepada peserta yang telah mengikuti program pemberdayaan hendaknya terus dilakukan sampai peserta program pemberdayaan benar-benar mampu memecahkan permasalahannya sendiri, terutama penyaluran kepada pengguna jasa.

\section{DAFTAR PUSTAKA}

Dikmenti Subdinas PLS. (2005). Pedoman penyelenggaraan PKBM di Provinsi DKI Jakarta. Jakarta: PemProv DKI.

Dirjen PLSP. (2004). Menuju masyarakat yang cerdas, terampil, dan mandiri. Jakarta: Direktorat pendidikan Masyarakat. Depdiknas.

Margono, S. (2000). Memantapkan posisi dan meningkatkan peran penyuluhan pembangunan dalam pembangunan. Dalam Proseding Seminar IPB Bogor: Pemberdayaan Sumber Daya Manusia Menuju Terwujudnya Masyarakat Madani. Pustaka Wira Usaha Muda.

Miles, \& Huberman, M. (1992). Analisa data kualitatif, buku tentang metode-metode baru. Jakarta: Universitas Indonesia, UI Press.

Moleong, L.J. (1996). Metodologi penelitian kualitatif. Bandung: Remaja Rosdakarya.

Sihombing, H. (1999). Pendidikan luar sekolah kini dan masa depan. Jakarta.

Sihombing, H. (2000). Pendidikan luar sekolah. Manajemen strategi. konsep, kiat, dan pelaksana. Jakarta

Sumaryo.(1991). Implementasi participatory rural appraisal (PRA) dalam pemberdayaan masyarakat. Disampaikan dalam Pelatihan Pengorganisasian Masyarakat dalam rangka Peningkatan Mutu Pengabdian pada Masyarakat, di IAIN Raden Intan Bandar Lampung, 26 November 2005.

Sumaryo. (1996). Berbuat bersama, berperan setara. Konsorsium Pengembangan Dataran Tinggi Nusatengata. Jakarta.

UPT Ditjen PLS. (2003). Standar minimal manajemen PKBM berbasis masyarakat. Bandung: BPKB Jayagiri. 